\title{
Choosing between Formal and Informal Technology Transfer Channels: Determining Factors among Spanish Academicians
}

\author{
Francisco I. Vega-Gomez *(D) and Francisco J. Miranda-Gonzalez (D) \\ Economic Faculty, Universidad de Extremadura, 06006 Badajoz, Spain; fmiranda@unex.es \\ * Correspondence: author: fvegagomez@unex.es
}

Citation: Vega-Gomez, F.I.; Miranda-Gonzalez, F.J. Choosing between Formal and Informal Technology Transfer Channels: Determining Factors among Spanish Academicians. Sustainability 2021, 13, 2476. https://doi.org/10.3390/ su13052476

Received: 5 February 2021

Accepted: 22 February 2021

Published: 25 February 2021

Publisher's Note: MDPI stays neutral with regard to jurisdictional claims in published maps and institutional affiliations.

Copyright: (c) 2021 by the authors. Licensee MDPI, Basel, Switzerland. This article is an open access article distributed under the terms and conditions of the Creative Commons Attribution (CC BY) license (https:/ / creativecommons.org/licenses/by/ $4.0 /)$.

\begin{abstract}
Technology transfer has become one of the most important activities that must be developed by universities. However, there are multiple ways to do it. We can differentiate, essentially, between formal transfer (which is carried out through the channels established and controlled by the university staff, legalized through contracts) and informal (channels not legalized by signing a contract). Both types of transfers have diverse implications, which is why their study is necessary. This research aimed to study what are the determinants that lead academics to choose one or another channel of technology transfer. To this end, an empirical study was carried out by sending a questionnaire ad hoc to which a total of 1215 researchers responded. The results show that the choice of formal transfer channels depends on the academic experience in informal channels, as well as on the capacity and that of organizational justice. These results have important implications for policy makers and university managers.
\end{abstract}

Keywords: management of technological innovation and R\&D; academic entrepreneurship; science transference channels; formal technology transfer; informal technology transfer; determining factors

\section{Introduction}

For many years, education and research were considered the only two missions of universities. However, in recent decades, universities have become increasingly multifaceted [1], more entrepreneurial, generating value for society through the commercial application of research results, which has come to be known as the "third mission" alongside the traditional tasks of education and research [2]. The transition to entrepreneurial universities has been stimulated by the pressures of policy makers who consider the commercialization of research a key source of innovation and of regional and national competitiveness as well as economic development [3].

Academic entrepreneurship, as it has been defined, is a key factor in the EU's strategy for sustainable development. Several studies have demonstrated the importance of this process to achieving sustainability [4,5]. The contribution of academic entrepreneurship to sustainable development and environmental care is also twofold, at both the micro and macro levels [6]. This is so not only when the research involved focuses on directly related issues such as the green and circular economy or bioeconomy [7], but also in any research and transfer process, as it improves existing technology [8]. That is why we consider it necessary to know what are the mechanisms that lead academics to choose one or another type of channel for entrepreneurship, given its implications for sustainability.

Some authors refer to entrepreneurial activity in the context of academic institutions (universities and public research organizations) as academic entrepreneurship or academic enterprise. Glassman et al. defined it broadly as the creation or use of an opportunity in a university context, taking the available resources into account [9]. This definition encompasses all possible entrepreneurial behaviors that are involved in the processes of innovation and strategic renewal and that are developed in an academic institution.

Other authors use the term academic entrepreneurship more narrowly, to refer only to the activities of transfer of research results carried out by universities and public research 
centers $[10,11]$. This is the definition that we use in our work; thus, we identify academic entrepreneurship with the transference of results.

Nevertheless, what is clear is that the transfer of technology to society has become the main instrument for carrying out entrepreneurial activity [12]. That is why interest in the phenomenon has increased in recent years, both among academics and universities and among policy makers, industry leaders, and society in general $[13,14]$. However, the phenomenon of technological transfer is multifaceted, and key questions such as how to carry out this transfer differ, depending on the nature of the relationship of the academy with industry and society. In this regard, authors, such as Grimpe and Hussinger, propose that a distinction be made between formal and informal transfer [3]. According to these authors, a formal transfer would be any one in which there is some type of legal contract signed between the industry (or some social entity) and the academic institution. Informal transfer, on the contrary, would be one that arises as a consequence of existing personal contacts and, therefore, involving the tacit dimension of the transfer of knowledge. Other authors, such as Balven et al., define formal transfer, along the same lines as the previous ones, as that which is produced by following legally established procedures for commercializing the results of research, while all those transfers that take place outside of these formally established channels are considered informal transfer [15]. The latter does not imply in any case violating any law or university policy [16]. In short, while formal transfer activities must necessarily pass through the technology transfer office (TTO) of the researcher's university, informal transfer activities are done outside the TTO. In the words of Markman et al. [17,18], informal transfer is the kind that takes place "going out the back door". All these definitions are in line with that provided by Link et al. [19].

Both dimensions have differences, as much in their implications for legal responsibilities as in the implementation processes, but they are completely complementary $[3,20]$, and thus should be considered in tandem with each other. Likewise, this relationship of complementarity between both types of transfer makes it necessary to study the relationship between the two types.

The leading authors on the subject of academic entrepreneurship have approached the topic using different methodologies and with data from different countries and institutional contexts $[3,19,20]$. However, the literature to date focuses on analyzing the formal mechanisms of academic entrepreneurship (patents, contracts/agreements, and spin-offs), with few studies analyzing informal mechanisms for knowledge transfer $[19,20]$ mainly on account of the greater difficulty in obtaining information on the latter [15].

The decision to carry out transfer activities (formal or informal) is a decision of an individual nature that has important consequences for the academy [19]. If an academic decides not to carry out academic entrepreneurship activities, even when having research results that may be useful to industry, that scholar's research activity (which is usually financed with public funds) will be of little value to society [21]. In the words of Link et al., we must focus on the individual level, because "certain research questions are better addressed by focusing directly on agents involved in technology commercialization, such as academic scientists" [19]. On the other hand, if one does opt for informal transfer but in a way that leaves the TTO out, the university loses an important source of funding derived from the various formal transfer mechanisms [20].

This paper contributes to the emerging body of literature about the differences between formal and informal transfer mechanisms, since prior research has focused on formal transfer activities. This is because, as noted, formal transfer systems such as patents, licenses, and the creation of spin-offs are easier to measure, while informal transfer mechanisms have remained in the background, with some exceptions that we analyze in the following section [22-25]. To help fill this gap, we explore the factors that determine entrepreneurial behavior on the part of academics, differentiating between formal and informal transfer mechanisms. Unlike most previous studies, the research in this study was directed at all existing universities in Spain and researchers from all branches of knowledge. In this way, in this article, we try to respond to the existing gap in the study of formal and informal 
transfer as a whole, seeking to discover the determinants at the individual level that lead academics to opt for one type of knowledge transfer or another. In addition, we aspire to study the relationship between the two types of transfer, with the central idea of knowing if they are complementary, as Grimpe and Hussinger and Dang et al. affirmed [3,20], all from the point of view of individual academics, the ultimate actors in their choices of one method of transfer or another.

The remainder of this article is structured as follows. In Section 2, we review the existing literature on formal and informal academic entrepreneurship, from which we propose the hypotheses of our model on the background of the transfer of results. Information on the methodology of the study and the design of the survey carried out are then presented. Next, the main results of our study are shown. Finally, the conclusions and limitations of the study are collected, and a proposal is presented for future lines of research.

\section{Literature Review}

\subsection{Background}

Although most of the literature has focused on analyzing formal transfer processes, several works have dealt with transfer activities carried on outside the formal channels. Thus, Siegel et al., in a qualitative analysis of five universities in the United States, detected that many researchers transfer results outside the formal channels established by the university, especially when those formal channels are inflexible and ineffective [26].

Hertzfeld et al., from interviews with the main property attorneys of 54 R\&D-intensive companies in the United States, discovered that companies had serious difficulties in dealing with university TTOs in matters of intellectual property [27]. These problems fundamentally involved the inexperience of TTO personnel, their lack of commercial knowledge, and their tendency to inflate the market potential of patents. Therefore, companies were looking for ways to avoid TTOs and deal directly with researchers, regardless of the procedures formally established by their universities.

Markman et al., based on their analysis of researchers from 54 US universities, demonstrated that informal transfer activities are reduced when TTOs enjoy greater autonomy and when the economic remuneration is increased for researchers involved in formal transfer activities [28]. At the same time, informal transfer increases when it comes to inventions with greater economic potential and when there is a strong business presence on the university campus. The importance of economic incentives in increasing formal transfer activities is also demonstrated in the work of Grimpe and Fier, based on a sample of more than 800 researchers from Germany and the United States [28].

On the other hand, Ponomariov and Boardman presented informal activities as acting as a prelude to formal ones, so that being involved in informal activities increases the probability of future participation in formal contracts in collaboration with the industry, and devoting more time to transfer activities [23].

For their part, Kang et al. analyzed a specific type of informal transfer activity that qualifies as "open transfer" [29]. When a researcher speaks in a forum or posts an answer on a question-and-answer (Q\&A) bulletin board, the knowledge incorporated into that speech or message can be transferred to anyone attending the forum or reading the message. Such knowledge transfers are a form of public communication and are classified as "open knowledge transfer". In this type of transfer, the source of the knowledge cannot control the number or type of its receivers, leaving little chance of establishing relationships with them. It is precisely these relationships that are the main factor in open transfer, as Robinson et al. [30], among others, concluded.

Particularly relevant is the work of D'Este and Perkmann, in which four main motivations of the researcher to interact with the productive sector are identified: to commercialize research results, to gain knowledge, to gain access to complementary financing for projects, and to gain access to other resources of the productive sector (equipment, data, etc.) [31]. The type of motivation determines whether or not the researcher will choose to utilize the formal transfer mechanisms. 
Other authors, such as Grimpe and Hussinger, have focused on looking more for the existence of effects of complementarity or antagonism between the two types of transfer. Their study of more than 2000 German manufacturing companies concludes that the two types of transfer are complementary, since "the use of informal technology transfer increases the marginal performance of formal technology transfer" [3]. From this conclusion, it stands to reason that, in addition to paying attention to the factors that determine the choice of one or another type of transfer, it is also important to observe the relationship between the two types of transfer; what is more, both can be beneficial to universities, so they should both be seen as a source of empowerment for universities.

Huyghe et al. argued that researchers do not always avoid TTOs intentionally, but sometimes, they bring their invention directly to the market simply because they do not know that the TTO exists or are unaware of the procedure established for making such a transfer. Therefore, Huyghe et al. concluded that greater visibility of these procedures would significantly increase formal transfer activities [32].

In addition, Goel and Göktepe-Hultén showed that researchers who have previously patented their results, have doctorates, and have previous experience in the productive sector are more likely to opt for informal transfer activities [33].

Along the same lines are the findings of Link et al., who, through a study of 1514 scientists, determined that informal transfer activities are reinforced by the need for recognition within the scientific community of academics [19]. In this manner, academic papers in leading journals; presentations at first-level institutions, conferences, and workshops; and research grants are key to attaining promotion in universities and, therefore, academics choose these types of transfer in the early stages of their academic careers. In addition, factors such as financial reward [34] and access to resources for research, elements that can often best be achieved through informal contacts with the industry, in many cases induce academics to choose to skip the TTO and consider informal transfer as the best way of transfer. Finally, these authors postulate that formal transfer entails much bureaucracy and consumes a great deal of time for academics, which is why, in many cases, informal transfer is preferable: it is less disruptive to the academic career and allows a greater amount of time for those other activities that are more "profitable" from the point of view of academic promotion.

Finally, Dang et al., by studying the transfer practices of 10 Australian universities, concluded that these institutions use informal channels in their common transfer simultaneously, using channels such as industry mentoring, internship, transdisciplinary research platforms, collaborative PhDs, industrial projects, and training programs [20]. In addition, these authors considered that these activities create a network of bidirectional interdependence that, far from being a hindrance to universities, governments, and industries, benefits all parties involved. These findings are consistent with the studies of Muscio and Vallanti [35] and Cheng et al. [36].

\subsection{Factors of Knowledge Transfer}

In the work of Siegel et al., three fundamental obstacles to academic entrepreneurship are identified: (1) the existence of informational and cultural barriers between companies and the universities; (2) inadequacy of existing rewards (monetary and nonmonetary) to encourage participation in formal technology transfer activities; and (3) limited business experience on the part of TTO staff, together with high turnover rates [37].

An analysis of the literature on knowledge transfer would allow us to identify the main factors that can influence the individual decision of a researcher to get involved in transfer activities and thus overcome those obstacles identified by Siegel et al. [38]. In this way, we agree with Argote et al. that, for successful knowledge management, there are three determining factors: capacity, motivation, and opportunity [38]. 


\subsubsection{Capacity}

The researcher's capabilities are an important part of the knowledge transfer process, as has been demonstrated in numerous studies carried out to date [39-42]. While the skills are innate, they can also be improved with instruction and training [43]. Thus, both previous experience in transfer activities [39] and the training programs established by the university have an important effect on the development of these skills [44].

\subsubsection{Motivation}

Rewards and incentives are a determining factor in the researcher's decision to get involved in transfer activities $[28,29]$, also influencing the decision as to whether to opt for formal or informal transfer channels [31]. In this study, we consider motivation to be the reward or desire for reward that the researcher pursues.

Researchers are not likely to transfer their knowledge if they are not rewarded for it. Several studies have shown the relationship between the percentage of monetary reward received by the researcher and the productivity of the transfer processes [5,34,45-47].

In addition, social rewards can be as important as monetary or curricular rewards: since noncooperative behavior damages the reputation of academics, some researchers are willing to make an additional effort to transfer knowledge and thus protect their social position [38].

\subsubsection{Opportunity}

Capacity and additional effort are even more valuable when combined with opportunity. The conditions of the environment in which researchers develop their activities can favor or hinder transfer activities. There are several works that highlight the important role of environmental or institutional factors on academic entrepreneurship, although these studies indicate that they are not sufficient by themselves to explain the higher performance of some universities compared to others [37,48,49].

Many works focus on analyzing the role of TTOs in the technology transfer procedure, trying to analyze the procedures for improving their efficiency and increasing the benefits to the parties involved in the transfer processes [50]. Thus, Lockett et al. demonstrated the relationship between the resources and capabilities of the TTO and the spin-off company generation rate [51].

\subsubsection{Organizational Justice}

Together with these three factors, and based on the results obtained in the qualitative study of Balven et al. [15], we propose to include a fourth determining factor: organizational justice. It is a cognitive process of each individual but related to the existing policies in the individual's organization. It is a variable widely studied in the general literature of "management" [52-54], based on the idea that the individual who feels fairly treated by the organization of which he or she is a part will feel an obligation to help achieve the organizational objectives. When the organizational objectives are not in line with knowledge transfer, but instead focus more on traditional academic activities, this can be a handicap to transferring knowledge [35].

Balven et al., through a qualitative study in the field of academic entrepreneurship, justified the importance of this organizational justice as a background for transfer activities, although to date this relationship has not been demonstrated with a quantitative study such as the one we propose [15].

Traditionally, this variable has been considered as a four-dimensional construct: distributive justice, procedural justice, interpersonal justice, and informational justice. In its adaptation to academic entrepreneurship, we could define these dimensions as follows:

- Distributive justice: The degree to which the reward obtained by the academic (economic or curricular benefit, etc.) is in accordance with the effort and sacrifice involved in engaging in a formal or informal transfer activity. 
- Procedural justice: The academic's perception of his or her relationship with the TTO staff (professionalism, effectiveness, etc.).

- Interpersonal justice: The academic's perception that the treatment received from the TTO is similar to that of others, regardless of seniority or professional category.

- Informational justice: The academic's perception of whether information related to transfer activities is explained in a personalized, clear, and timely manner.

- In addition to these four traditional dimensions, we agree with Balven et al. [15] on the need to incorporate a fifth dimension: deontological justice. This fifth dimension refers to the academic's perception of the moral desirability of transfer activities and their relationship with the third mission of the university. Thus, many academics see in the transfer of technology the raison d'être of their research activity, since they consider it morally fair to return to society what it has allowed them to develop thanks to the public funds received to finance their research projects. Others, on the contrary, consider that transfer activities "distract" the academic from the real missions of academia [19].

\subsection{The Proposed Model}

The existing literature suggests that formal and informal transfer of technology are often linked [3,20,37], as informal contacts improve the quality of a formal relationship and as formal contracts are accompanied by informal relationships of mutual exchange on aspects related to technology. Therefore, we propose a model that tries to analyze the relationships between the main determinants of transfer activities (capacity, motivation, opportunity, and justice), as well as between the two modalities of knowledge transfer identified (see Figure 1).

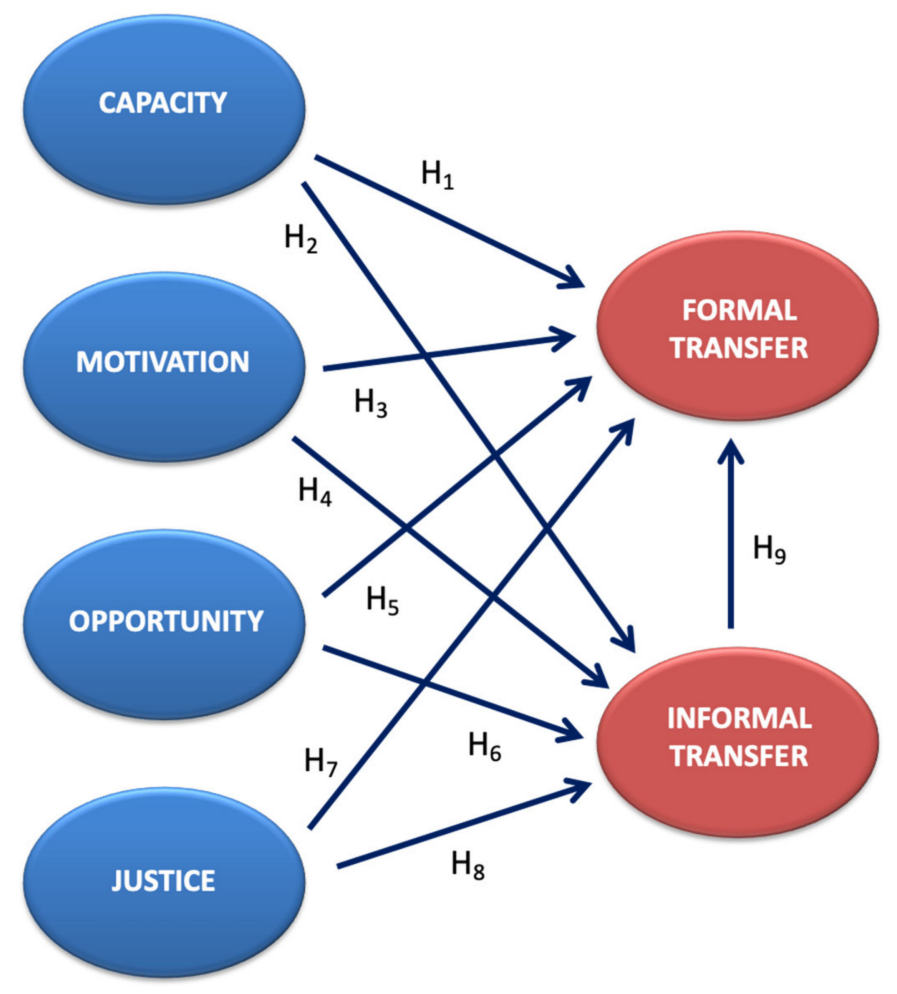

Figure 1. Structural model.

In the paragraphs that follow, we analyze the different variables that make up the proposed model, justifying the proposed relationships. 


\subsubsection{Capacity}

Whether one refers to capacities, aptitudes, abilities, or perceived control, there is abundant research that demonstrates that, to carry out any transfer activity, it is necessary that the academic perceive that he or she has what it takes to successfully carry out said activity $[40-43,55]$.

Therefore, we propose the following hypotheses:

H1: The greater the self-perceived capacity of the academic is, the greater the academic's involvement in formal transfer activities will be.

H2: The greater the self-perceived capacity of the academic is, the greater the academic's involvement in informal transfer activities will be.

To measure this construct, we used a seven-item scale adapted from the model proposed by Obschonka et al. [42] and Fernández-Pérez et al. [41] to measure the person's confidence in his or her own ability to carry out the tasks required for performing knowledge transfer activities.

\subsubsection{Motivation}

A second group of factors that determine participation in transfer activities consists of the so-called motivational factors. In the literature, we find numerous papers that empirically demonstrate the relationship between academic entrepreneurship activities and the motivation of the researcher to get involved in these types of activities [5,28,29,32,48].

Therefore, we propose the following hypotheses:

H3: The greater is the motivation of the academic, the greater will be the academic's involvement in formal transfer activities.

H4: The greater is the motivation of the academic, the greater will be the academic's involvement in informal transfer activities.

To measure this construct, we used a six-item scale adapted from the model proposed by Miranda et al. [56] to measure the person's level of motivation to carry out the tasks required for performing knowledge transfer activities.

\subsubsection{Opportunity}

The literature on entrepreneurship suggests that entrepreneurial initiative is related to both the opportunities that exist in the economy and the presence of entrepreneurial individuals who can exploit them $[5,48,55,57]$. The opportunities to develop transfer activities are greater in environments where there are regional and university policies geared towards fostering an innovative ecosystem in which an intense relationship exists between the productive fabric and the knowledge-generating entities (universities and research centers).

We therefore propose the following hypotheses:

H5: The greater is the opportunities offered by the environment, the greater will be the involvement of the academic in formal transfer activities.

H6: The greater is the opportunities offered by the environment, the greater will be the involvement of the academic in informal transfer activities.

To measure this construct, we used a six-item scale adapted from the model proposed by Díaz-Casero et al. [58].

\subsubsection{Justice}

From the qualitative study of Balven et al. [15], we consider as a fourth determining factor of knowledge transfer activity the perception that the academic has about how fair the relationship with his or her organization is when performing results transfer activities. We concur with Balven that, if the researcher perceives unfairness in the process established 
by the organization, it will be more difficult to be involved in formal transfer activities, opting for informal channels if the scholar is determined to make that transfer.

Therefore, we propose the following hypotheses:

H7: The greater is the perceived justice, the greater will be the involvement of the academic in formal transfer activities.

H8: The greater is the perceived justice, the greater will be the involvement of the investigator in formal transfer activities.

To measure this construct, we developed a scale of five items gathering the dimensions identified in the aforementioned study by Balven et al. [15].

Lastly, we agree with Balven et al. [15] that there is a relationship between the two types of transfer activities that to date has not been empirically demonstrated. Although the causality of this relationship has not been demonstrated, we understand that it is prior participation in informal transfer activities that allows the academic to know firsthand the needs and possibilities offered by the market and to consider subsequent involvement in transfer activities of a formal nature. Therefore, we propose a final hypothesis:

H9: The greater is the prior involvement of the academic in informal transfer activities, the greater will be the academic's involvement in formal transfer activities.

Finally, we included in our study a series of control variables that reflect the characteristics of the individual researcher and his or her organizational environment:

- Age

- Gender

- Academic field

- Geographic location

\section{Materials and Methods}

We directed our study to all academics involved in teaching and/or research activities at the 82 existing universities in Spain in 2019. In the absence of a comprehensive list of active academic staff, the sample framework was built from the information available on the universities' websites, covering a total of 1030 centers (faculties and schools) and 2998 university departments. The questionnaire was designed in an online format and distributed via email. In those cases in which email addresses were not available, the collaboration of the heads of the different centers and departments was solicited to distribute the questionnaire among their members.

Finally, 1215 valid responses were obtained, which represents a sampling error of $2.8 \%$ (see Table 1). This work, following the line initiated by the study of Abreu and Grinevich in the United Kingdom [59], is a pioneering effort in analyzing all the scientific fields, institutions, and professional categories of a country.

Table 1. Data sheet.

\begin{tabular}{|c|c|}
\hline Universe & $\begin{array}{c}\text { Teaching and Research Staff of the } 82 \text { Spanish } \\
\text { Universities (115,332 Individuals) }\end{array}$ \\
\hline Geographic scope & Spain \\
\hline Data collection method & Online survey \\
\hline Sample size & 1215 questionnaires received \\
\hline Sample error & $\begin{array}{l}\text { For a } 95 \% \text { confidence level and } \mathrm{P}=\mathrm{Q} \text {, the error for the } \\
\text { whole sample is } \pm 2.8 \%\end{array}$ \\
\hline Fieldwork & January 2020 \\
\hline
\end{tabular}

If we compare our sample with official statistics [60], we observe its representativeness in terms of seniority, gender, and research field: $64 \%$ of respondents are men; $75 \%$ have 
been in the institution for more than 15 years; and 33.8\% work in social fields, $22.7 \%$ in scientific, $18.5 \%$ in technical, $13.2 \%$ in biomedical, and $11.8 \%$ in the humanities.

The data analysis method chosen is the partial least squares regression (PLS) technique [61]. In this study, PLS was used, on the one hand, because the technique is designed primarily for predictive analysis in which the problems explored show complexity, and, on the other hand, because theoretical knowledge has not yet reached a level of critical maturity. In addition, PLS has advantages over LISREL in the initial stages of development and verification of theories, where the proposed models have an exploratory and nonconfirmatory nature and there are few empirically validated models, as is our case. The model was estimated using SmartPLS 3.0, and the significance of the parameters was established by a bootstrap resampling procedure of 500 subsamples of a size equal to the original sample.

\section{Results}

The relationship model was analyzed taking into account the individual reliability of the items and the discriminant validity of the constructs [62]. As regards the individual reliability of each item, its valuation is based on the loads, taking as a general rule that they must exceed the reference value of 0.707 [63]. If we consider that the charges are correlations, a level equal to or greater than the one proposed implies that more than $50 \%$ of the variance of the observed variable is shared by the construct, that is, the variance shared between the construct and its indicators is greater than the variance of the error. Some authors argue that in exploratory studies such as ours it is possible to accept values that are somewhat lower than the reference. After a process of debugging the scales, as shown in Table 2, it can be verified that the resulting items have loads close to or greater than the reference value. Those with lower loads were included since they come from scales designed for other types of relationships, which reflects the exploratory nature of the research and its impact on the level of reliability and validity of the other indicators that make up the construct.

Table 2. Evaluation of the measurement model.

\begin{tabular}{|c|c|c|c|c|}
\hline Constructs & $\begin{array}{l}\text { Loading } \\
\text { Factors }\end{array}$ & $\begin{array}{l}\text { Cronbach's } \\
\text { Alpha }\end{array}$ & $\begin{array}{l}\text { Composite } \\
\text { Reliability }\end{array}$ & Ave \\
\hline $\begin{array}{c}\text { Capacity } \\
\text { Obschonka et al. [40] and Fernández-Pérez et al. [41] }\end{array}$ & & 0.803 & 0.859 & 0.504 \\
\hline $\begin{array}{l}\text { CAPAC1: I have confidence in my ability to transfer valuable } \\
\text { knowledge to society. }\end{array}$ & 0.726 & & & \\
\hline $\begin{array}{c}\text { CAPAC2: I have the knowledge to solve problems relevant to the } \\
\text { productive sector of my environment. }\end{array}$ & 0.759 & & & \\
\hline CAPAC4: I am qualified to be the promoter of a spin-off. & 0.647 & & & \\
\hline $\begin{array}{l}\text { CAPAC5: I am qualified to sign a service contract (art. 83) with a } \\
\text { company outside the university. }\end{array}$ & 0.732 & & & \\
\hline $\begin{array}{l}\text { CAPAC6: I am qualified to advise others on the implications of } \\
\text { my research results. }\end{array}$ & 0.702 & & & \\
\hline $\begin{array}{l}\text { CAPAC7: Many of my colleagues believe that the results of my } \\
\text { research are of significant value for society. }\end{array}$ & 0.687 & & & \\
\hline $\begin{array}{l}\text { Opportunity } \\
\text { Díaz-Casero et al. [58] }\end{array}$ & & 0.814 & 0.867 & 0.569 \\
\hline $\begin{array}{l}\text { OPORT1: My university has adequate procedures and policies to } \\
\text { facilitate the transfer of results to the productive sector. }\end{array}$ & 0.854 & & & \\
\hline $\begin{array}{l}\text { OPORT2: My university has adequate procedures and policies to } \\
\text { locate companies that would be interested in the results obtained } \\
\text { by my research group. }\end{array}$ & 0.814 & & & \\
\hline $\begin{array}{l}\text { OPORT3: My university has adequate procedures and policies to } \\
\text { assess the value of research results (prototypes, market tests, etc.). }\end{array}$ & 0.732 & & & \\
\hline
\end{tabular}


Table 2. Cont.

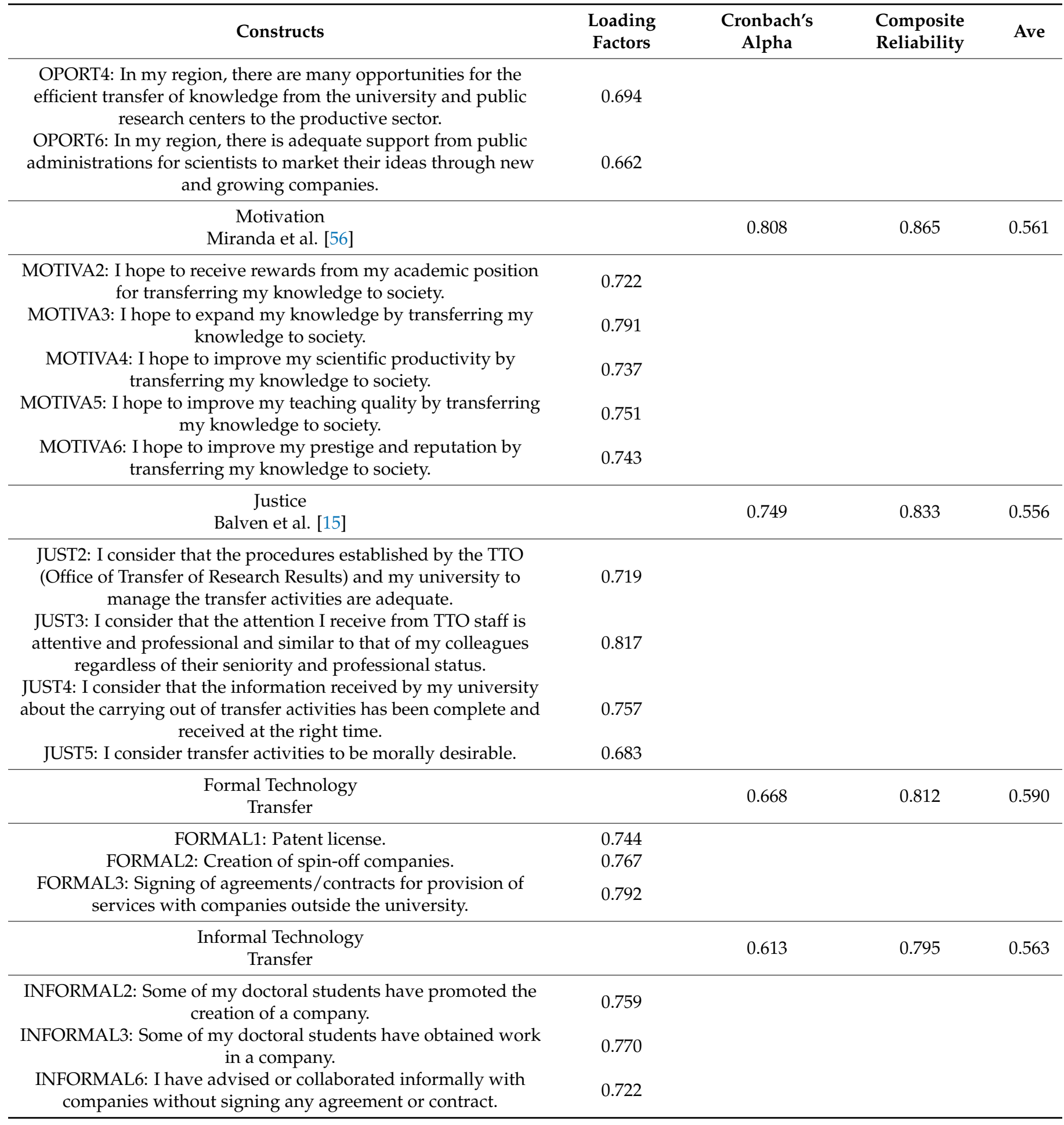

As shown in Table 2, the value of Cronbach's alpha for each construct is between 0.613 and 0.814 , which is indicative of good reliability between the indicators of each construct. In turn, the composite reliability of all constructs exceeds the reference limit of 0.7 , even the strictest of 0.8 [64]. In addition, the values of the averages of the extracted variance (AVE) are greater than 0.5 , ensuring the convergent validity of the model [65].

Finally, to evaluate the discriminant validity of the constructs, it was found that no item presented higher loads in other constructs than in the one it was intended to measure [66]. A construct will have discriminant validity if its AVE is greater than the 
square of the correlations of its construct with the others [66]. All model constructs have discriminant validity (see Table 3), so we can proceed to evaluate the structural model. In addition, the highest value of the heterotrait-monotrait (HTMT) correlation ratio is 0.768 (see Table 4) and, therefore, supports discriminant validity [67].

Table 3. Discriminant validity (Fornell-Larcker criterion).

\begin{tabular}{ccccccc}
\hline & Capacity & Justice & Motivation & Opportunity & Formal TT & Informal TT \\
\hline Capacity & 0.710 & & & & & \\
Justice & 0.389 & 0.746 & & & & \\
Motivation & 0.447 & 0.375 & 0.749 & & & \\
Opportunity & 0.229 & 0.513 & 0.195 & 0.754 & 0.768 & \\
Formal Transfer & 0.457 & 0.252 & 0.177 & 0.139 & 0.464 & 0.751 \\
Informal Transfer & 0.406 & 0.195 & 0.202 & 0.114 & 0.45 \\
\hline
\end{tabular}

Note: The diagonal elements are the stable root of the AVE.

Table 4. Discriminant validity (heterotrait-monotrait Ratio (HTMT)).

\begin{tabular}{ccccccc}
\hline & Capacity & Justice & Motivation & Opportunity & Formal TT & Informal TT \\
\hline Capacity & & & & & & \\
Justice & 0.454 & & & & & \\
Motivation & 0.561 & 0.426 & & & & \\
Opportunity & 0.264 & 0.707 & 0.227 & & \\
Formal Transfer & 0.574 & 0.308 & 0.204 & 0.178 & 0.701 & \\
Informal & 0.565 & 0.246 & 0.265 & 0.155 & & \\
\hline
\end{tabular}

With respect to formal and informal transfer activities, following Grimpe and Hussinger, Grimpe and Fier, Link et al., and Dang et al. $[3,19,20,28]$, we consider that they can be classified as follows.

Informal transfer activities:

(a) sharing research results on open science platforms;

(b) a doctoral student promoting the creation of a company;

(c) a doctoral student being hired by a company;

(d) an academic researcher answering questions from other colleagues in open network forums;

(e) a researcher participating in forums, seminars, and conferences where research results are openly shared; and

(f) an investigator advising a company without signing any contract or agreement.

Formal transfer activities:

(a) taking out a patent license;

(b) creating a university spin-off; and

(c) signing an agreement or contract for the provision of services to companies outside the university.

Regarding the collinearity assessment, all IVF values of both the external model and the structural model are below the reference limit (ranging from 1.094 to 2.172).

Figure 2 shows the results of the estimation of our structural model. The arrows indicate causal relationships, and the number next to each of them represents its standardized coefficient. The product of said standardized coefficient and the correlation coefficient between the two constructs, expressed as a percentage, appears in brackets [68]. 


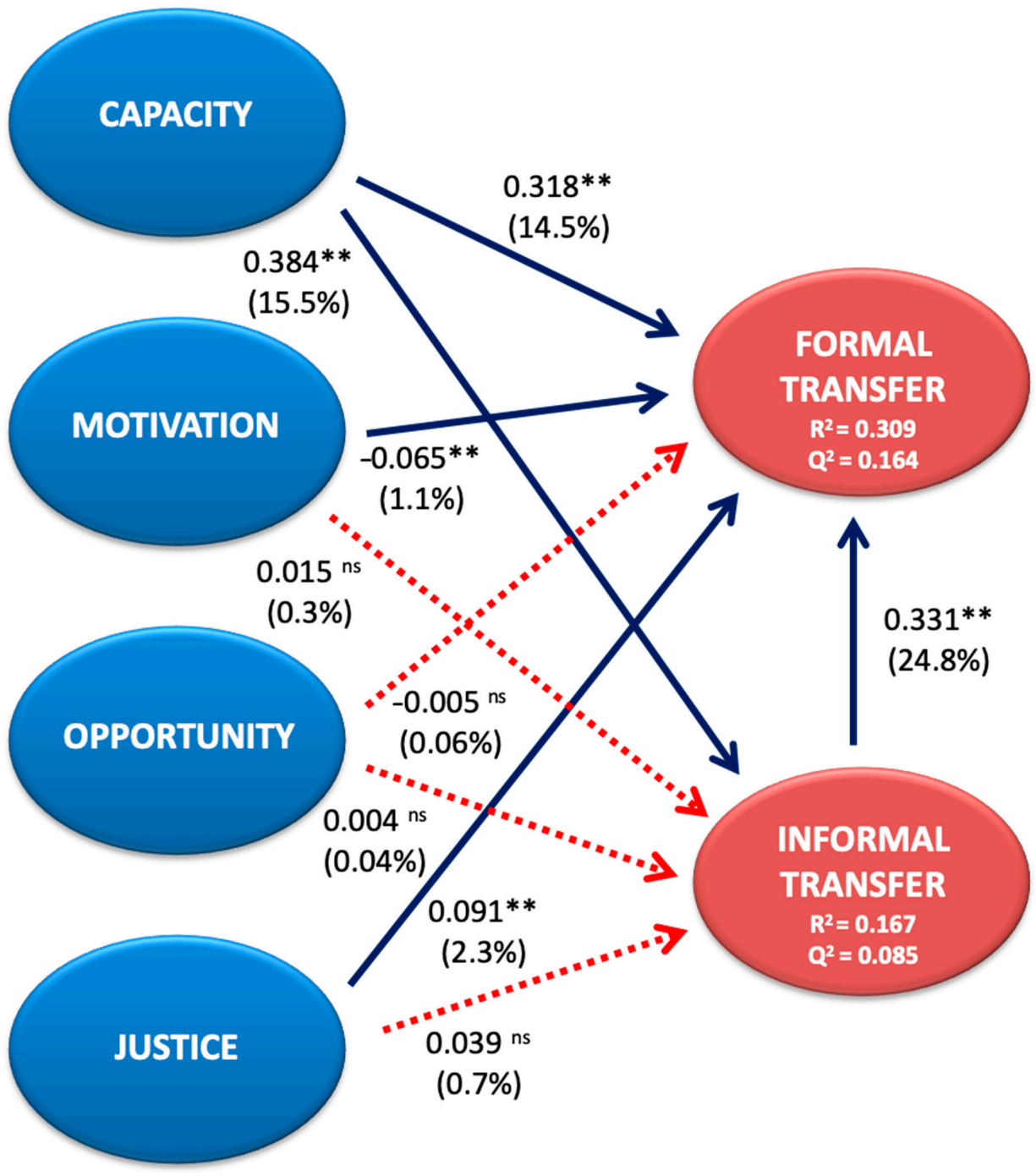

Figure 2. Estimation of the structural model. * relationship significant at $95 \%$; ** relationship significant at $99 \%$; ns, nonsignificant.

The magnitudes of the path coefficients are observed as standardized values in a range from +1 to -1 ; the higher is the value, the greater is the relationship (prediction) between constructs, and the closer it is to 0 , the lower is the convergence to the construct. If the result of a path value is contrary to the sign postulated in the hypothesis, this indicates that the hypothesis is not supported. The level of significance is determined from the value of the T-Student that derives from the resampling or bootstrapping process with 500 subsamples, which is a nonparametric technique (there are no initial parameters; it is tested whether the paths between variables are feasible), which evaluates the accuracy of the PLS estimates.

Capacity is the only construct that contributes significantly to the explanation of informal transfer (15.5\%). The other three constructs do not prove significant to explain these types of activities. For its part, formal transfer is explained first by informal transfer $(24.8 \%)$, secondly by capacity $(14.5 \%)$, and thirdly by justice $(2.3 \%)$. Motivation also influences formal transfer (1.1\%), albeit with a sign contrary to that expected.

The figure shows that all the values of the Stone-Geiser $Q^{2}$ test have predictive relevance, as they are greater than zero. The model shows a moderate predictive power $\left(\mathrm{R}^{2}\right)$, as it contributes to explain $30.9 \%$ of the variance of formal transfer activities and $16.7 \%$ of informal transfer activities. The goodness-of-fit value is calculated through the standardized mean square residual (SRMR), which is equal to 0.08 , meaning that our model conforms to the empirical data [69]. 


\section{Discussion}

We verified, through a theoretical model, the influence that certain variables have on the carrying out of transfer activities by an academic. The model demonstrated its capacity as a conceptual framework by explaining $30 \%$ of the variance of formal transfer activities, a result similar to that obtained in previous studies on academic entrepreneurship.

According to our study, formal transfer activities depend fundamentally on the previous experience of the respondent in informal transfer activities. As noted, this is the first time that this relationship has been empirically demonstrated. The results suggest that researchers experience the transfer of research results for the first time informally, regardless of the procedures established in their university, and that it is only when they verify that their knowledge is valid for solving problems in the productive sector and may have commercial viability that they contact the TTO to formalize these transfer activities.

The second determining factor of formal transfer activities is capacity. Whether it is spoken of in terms of capacities, aptitudes, abilities, or perceived control, there is abundant work that demonstrates that, for those individuals to carry out any transfer activity, it is necessary that the research scholar perceive that he or she has what it takes to develop said activity successfully $[40-43,58]$. Therefore, the best way to improve the transfer results of an institution is to train its researchers in the transfer of research results so that they feel comfortable when facing the procedures associated with the transfer of results to society.

Our study manages for the first time to demonstrate the influence of the organizational justice construct on transfer activities, as theoretically proposed in the aforementioned work by Balven et al. [15]. Those academics who perceive their relationship with the TTO staff (in terms of professionalism, effectiveness, etc.) and the explanation of the information related to transfer activities as fair, and who consider the transfer activities morally desirable, are the most engaged in these types of activities. Therefore, if a university wishes to increase its transfer results, it must invest its resources in designing an TTO with flexible and efficient procedures and with adequately trained personnel so as to quickly resolve any doubts that may arise when a researcher begins the procedure to transfer a research result.

As previously stated, we must reject the hypothesis that motivation determines formal transfer activities, since, although its sign is significant, it is contrary to what is expected. This result calls into question the influence of rewards and incentives as a determining factor in the researcher's decision to get involved in transfer activities and, therefore, the results obtained in previous work $[5,47]$. This unexpected result seems to indicate that for the researchers surveyed it is not the expected rewards that influence their involvement in transfer activities, but rather the moral desirability of these activities that drives them to make this transfer of their results to society.

Our results show that environmental or contextual factors (opportunity) have no influence on the involvement of researchers in transfer activities. This unexpected result must be questioned since the analysis was carried out at the national level where the differences between the different regional environments may not be significant. Our study seems to confirm that, in sociocultural and academic environments with little entrepreneurial tradition, the entrepreneurial intention does not depend so much on the opportunities as on the personalities of the academics themselves [5].

Concerning the determinants of informal transfer activities, only the capacity of researchers was found to be significant. As noted above, this is the first time that the factors that determine informal transfer activities have been analyzed empirically, so it is an exploratory study that demonstrates the need to perform further work analyzing other possible determinants of these activities not included in our model.

Despite the effort we have put into the design of our research, our study is not without limitations. A common limitation to this type of study is that derived from self-selection bias, since people who are already interested in the subject being studied are more likely to respond to this type of survey.

In addition, the measuring instruments used are based on the subjective perceptions of the academics surveyed, and thus they have a subjective component and are subject to 
social desirability biases. However, by ensuring the anonymity of the information provided by the academics surveyed, an attempt has been made to minimize this factor.

Thirdly, our study is exploratory and of a transversal nature, which makes it difficult to establish causal relationships in the variables of our model. Therefore, it is advisable to conduct a longitudinal study that can confirm these causal relationships.

Finally, the population studied here is limited to a specific geographical framework, so extreme caution should be exercised in generalizing the results to other countries or regions.

\section{Conclusions}

As Siegel and Wright pointed out, the literature on academic entrepreneurship has thus far focused primarily on work with university-level data, with fewer studies using data at the individual level [70]. That is why there is a large gap in the knowledge of the variables that determine the decision of an academic to become involved in knowledge transfer activities, either following the formal channels, or especially when it is carried out outside of these channels.

The development of the theoretical model that was empirically tested in this study was based on the research opportunities identified during the literature review. A significant effort was made to ensure the representativeness of the data with respect to the population under study, which, given the size of the total sample obtained, allowed for assurance of sufficiently low levels of sampling error, as well as a sample level suitable for the use of structural equation modeling as a statistical technique to test the hypotheses and the relationships proposed.

As the main contributions of this work, we can point first of all to the empirical confirmation of the existence of a relationship between formal and informal transfer activities. This relationship must be analyzed in future studies, using longitudinal data, in order to correctly analyze the causality of that relationship.

A second contribution lies in the identification of organizational justice as one of the factors of formal transfer activities, empirically confirming what was suggested in previous qualitative works.

Finally, this exploratory work opens the door to new research in the field of informal transfer, which allows for identifying the factors that determine the involvement of academic researchers in these types of activities, given that in the present work it is confirmed that the factors which have traditionally been used to explain formal transfer activities are not valid for explaining informal activities.

Author Contributions: Both authors have contributed to every part of the article. Both authors have read and agreed to the published version of the manuscript.

Funding: This research was funded by Junta de Extremadura and European Union (FSE-FEDER), grant number IB16007 and PD16045.

Data Availability Statement: The data presented in this study are available on request from the corresponding author.

Conflicts of Interest: The authors declare no conflict of interest.

\section{References}

1. Belitski, M.; Aginskaja, A.; Marozau, R. Commercializing university research in transition economies: Technology transfer offices or direct industrial funding? Res. Policy 2019, 48, 601-615. [CrossRef]

2. Rothaermel, F.T.; Agung, S.D.; Jiang, L. University entrepreneurship: A taxonomy of the literature. Ind. Corp. Chang. 2007, 16, 691-791. [CrossRef]

3. Grimpe, C.; Hussinger, K. Formal and informal knowledge and technology transfer from academia to industry: Complementarity effects and innovation performance. Ind. Innov. 2013, 20, 683-700. [CrossRef]

4. Qian, X.D.; Xia, J.; Liu, W.; Tsai, S.B. An empirical study on sustainable innovation academic entrepreneurship process model. Sustainability 2018, 10, 1974. [CrossRef]

5. Vega-Gomez, F.-I.; Miranda, F.J.; Chamorro Mera, A.; Pérez Mayo, J. The spin-off as an instrument of sustainable development: Incentives for creating an academic USO. Sustainability 2018, 10, 4266. [CrossRef] 
6. Wright, M. Academic entrepreneurship, technology transfer and society: Where next? J. Technol. Transf. 2018, 39, 322-334. [CrossRef]

7. Oguntuase, O.J. Academic entrepreneurship, bioeconomy, and sustainable development. In Handbook of Research on Approaches to Alternative Entrepreneurship Opportunities; Leitão Dantas, J.G., Carvalho, L.C., Eds.; IGI Global: Hershey, PA, USA, 2020 ; pp. 32-57.

8. Padilla Meléndez, A.; Aguila-Obra, D.; Rosa, A.; Lockett, N.; Fuster, E. Entrepreneurial universities and sustainable development: The network bricolage process of academic entrepreneurs. Sustainability 2020, 12, 1403. [CrossRef]

9. Glassman, A.M.; Moore, R.W.; Rossy, G.L.; Neupert, K.; Napier, N.K.; Jones, D.E.; Harvey, M. Academic entrepreneurship: Views on balancing the Acropolis and the Agora. J. Manag. Inq. 2003, 12, 353-374. [CrossRef]

10. Audretsch, D.B.; Aldridge, T.T.; Oettl, A. The knowledge filter and economic growth: The role of scientist entrepreneurship. Kauffman Found. Large Res. Proj. Res. 2006. [CrossRef]

11. Renault, C.S. Academic capitalism and university incentives for faculty entrepreneurship. J. Technol. Transf. 2006, 31, 227-239. [CrossRef]

12. Ahn, J.M.; Roijakkers, N.; Fini, R.; Mortara, L. Leveraging open innovation to improve society: Past achievements and future trajectories. RED Manag. 2019, 49, 267-278.

13. Chen, F.; Wu, C.; Yang, W. A new approach for the cooperation between academia and industry: An empirical analysis of the triple helix in East China. Sci. Technol. Soc. 2016, 21, 181-204. [CrossRef]

14. Guerrero, M.; Urbano, D. Effectiveness of technology transfer policies and legislation in fostering entrepreneurial innovations across continents: An overview. J. Technol. Transf. 2019, 44, 1347-1366. [CrossRef]

15. Balven, R.; Fenters, V.; Siegel, D.S.; Waldman, D. Academic entrepreneurship: The roles of identity, motivation, championing, education, work-life balance, and organizational justice. Acad. Manag. Perspect. 2018, 32, 21-42. [CrossRef]

16. Greenbaum, D.; Scott, C. Hochschullehrerprivileg-A modern incarnation of the professor's privilege to promote university to industry technology transfer. Sci. Technol. Soc. 2010, 15, 55-76. [CrossRef]

17. Markman, G.D.; Gianodis, P.T.; Phan, P. Sidestepping the Ivory Tower: Rent Appropriations through Bypassing of US Universities; Mimeograph; University of Georgia: Athens, Georgia, 2006.

18. Markman, G.; Gianiodis, P.; Phan, P. An agency theoretic study of the relationship between knowledge agents and university technology transfer offices. IEEE Trans. Eng. Manag. 2006, 55, 29-36. [CrossRef]

19. Link, A.N.; Siegel, D.S.; Bozeman, B. An empirical analysis of the propensity of academics to engage in formal university technology transfer. In Universities and the Entrepreneurial Ecosystem; Audretsch, D.B., Link, A.N., Eds.; Edward Elgar Publishing: Cheltenham, UK, 2017; pp. 97-111.

20. Dang, Q.T.; Jasovska, P.; Rammal, H.G.; Schlenker, K. Formal-informal channels of university-industry knowledge transfer: The case of Australian business schools. Knowl. Manag. Res. Pract. 2019, 17, 384-395. [CrossRef]

21. Fini, R.; Rasmussen, E.; Siegel, D.; Wiklund, J. Rethinking the commercialization of public science: From entrepreneurial outcomes to societal impacts. Acad. Manag. Perspect. 2018, 32, 4-20. [CrossRef]

22. Meyer-Krahmer, F.; Schmoch, U. Science-based technologies: University-industry interactions in four fields. Res. Policy 1998, 27, 835-851. [CrossRef]

23. Ponomariov, B.; Boardman, P.C. The effect of informal industry contacts on the time university scientists allocate to collaborative research with industry. J. Technol. Transf. 2008, 33, 301-313. [CrossRef]

24. Martinelli, A.; Meyer, M.; Von Tunzelmann, N. Becoming an entrepreneurial university? A case study of knowledge exchange relationships and faculty attitudes in a medium-sized, research-oriented university. J. Technol. Transf. 2008, 33, 259-283. [CrossRef]

25. Perkmann, M.; Walsh, K. University-industry relationships and open innovation: Towards a research agenda. Int. J. Manag. Rev. 2007, 9, 259-280. [CrossRef]

26. Siegel, D.S.; Waldman, D.A.; Atwater, L.E.; Link, A.N. Toward a model of the effective transfer of scientific knowledge from academicians to practitioners: Qualitative evidence from the commercialization of university technologies. J. Eng. Technol. Manag. 2004, 21, 115-142. [CrossRef]

27. Hertzfeld, H.R.; Link, A.N.; Vonortas, N.S. Intellectual property protection mechanisms in research partnerships. Res. Policy 2006, 35, 825-838. [CrossRef]

28. Markman, G.D.; Gianiodis, P.T.; Phan, P.H. Full-time faculty or part-time entrepreneurs. IEEE Trans. Eng. Manag. 2008, 55, 29-36. [CrossRef]

29. Kang, M.; Kim, Y.G.; Bock, G.W. Identifying different antecedents for closed vs open knowledge transfer. J. Inf. Sci. 2010, 36, 585-602. [CrossRef]

30. Robinson, S.; Lockett, N.; Johnston, L. Recognising “open innovation" in HEI-industry interaction for knowledge transfer and exchange. Int. J. Entrep. Behav. Res. 2010, 16, 540-560.

31. D'Este, P.; Perkmann, M. Why do academics engage with industry? The entrepreneurial university and individual motivations. J. Technol. Transf. 2011, 36, 316-339. [CrossRef]

32. Huyghe, A.; Knockaert, M.; Piva, E.; Wright, M. Are researchers deliberately bypassing the technology transfer office? An analysis. Small Bus. Econ. 2016, 47, 589-607. [CrossRef]

33. Goel, R.K.; Göktepe-Hultén, D. What drives academic patentees to bypass TTOs? Evidence from a large public research organisation. J. Technol. Transf. 2018, 43, 240-258. [CrossRef] 
34. Link, A.N.; Siegel, D.S. Generating science-based growth: An econometric analysis of the impact of organizational incentives on university-industry technology transfer. Eur. J. Financ. 2005, 11, 169-181. [CrossRef]

35. Muscio, A.; Vallanti, G. Perceived obstacles to university-industry collaboration: Results from a qualitative survey of Italian academic departments. Ind. Innov. 2014, 21, 410-429. [CrossRef]

36. Cheng, H.; Zhang, Z.; Huang, Q.; Liao, Z. The effect of university-industry collaboration policy on universities' knowledge innovation and achievements transformation: Based on innovation chain. J. Technol. Transf. 2020, 45, 522-543. [CrossRef]

37. Siegel, D.S.; Waldman, D.; Link, A. Assessing the impact of organizational practices on the relative productivity of university technology transfer offices: An exploratory study. Res. Policy 2003, 32, 27-48. [CrossRef]

38. Argote, L.; McEvily, B.; Reagans, R. Managing knowledge in organizations: An integrative framework and review of emerging themes. Manag. Sci. 2003, 49, 571-582. [CrossRef]

39. Goethner, M.; Obschonka, M.; Silbereisen, R.K.; Cantner, U. Scientists' transition to academic entrepreneurship: Economic and psychological determinants. J. Econ. Psychol. 2012, 33, 628-641. [CrossRef]

40. Obschonka, M.; Goethner, M.; Silbereisen, R.K.; Cantner, U. Social identity and the transition to entrepreneurship: The role of group identification with workplace peers. J. Vocat. Behav. 2012, 80, 137-147. [CrossRef]

41. Fernández-Pérez, V.; Esther Alonso-Galicia, P.; Del Mar Fuentes-Fuentes, M.; Rodriguez-Ariza, L. Business social networks and academics' entrepreneurial intentions. Ind. Manag. Data Syst. 2014, 114, 292-320. [CrossRef]

42. Obschonka, M.; Silbereisen, R.K.; Cantner, U.; Goethner, M. Entrepreneurial self-identity: Predictors and effects within the theory of planned behavior framework. J. Bus. Psychol. 2014, 30, 773-794. [CrossRef]

43. Nadler, J.; Thompson, L.; Van Boven, L. Learning negotiation skills: Four models of knowledge creation and transfer. Manag. Sci. 2003, 49, 529-540. [CrossRef]

44. Siegel, D.S.; Phan, P.H. Analyzing the effectiveness of university technology transfer: Implications for entrepreneurship education. In University Entrepreneurship and Technology Transfer; Libecap, B., Ed.; Emerald Group Publishing: Bradford, UK, 2006; pp. 1-38.

45. Friedman, J.; Silberman, J. University technology transfer: Do incentives, management, and location matter? J. Technol. Transf. 2003, 28, 17-30. [CrossRef]

46. Lach, S.; Schankerman, M. Royalty sharing and technology licensing in universities. J. Eur. Econ. Assoc. 2004, 2, 252-264. [CrossRef]

47. Gerhart, B.; Fang, M. Pay, intrinsic motivation, extrinsic motivation, performance, and creativity in the workplace: Revisiting long-held beliefs. Annu. Rev. Organ. Psychol. Organ. Behav. 2015, 2, 489-521. [CrossRef]

48. Autio, E.; Kenney, M.; Mustar, P.; Siegel, D.; Wright, M. Entrepreneurial innovation: The importance of context. Res. Policy 2014, 43, 1097-1108. [CrossRef]

49. Yoshioka-Kobayashi, T. Institutional factors for academic entrepreneurship in publicly owned universities in Japan: Transition from a conservative anti-industry university collaboration culture to a leading entrepreneurial university. Sci. Technol. Soc. 2019, 24, 423-445. [CrossRef]

50. Lichtenthaler, U. Open innovation: Past research, current debates, and future directions. Acad. Manag. Perspect. 2011, $25,75-93$.

51. Lockett, A.; Siegel, D.; Wright, M.; Ensley, M.D. The creation of spin-off firms at public research institutions: Managerial and policy implications. Res. Policy 2005, 34, 981-993. [CrossRef]

52. Colquitt, J.A. On the dimensionality of organizational justice: A construct validation of a measure. J. Appl. Psychol. 2001, 86, 386-400. [CrossRef]

53. Lavelle, J.J.; Rupp, D.E.; Brockner, J. Taking a multifoci approach to the study of justice, social exchange, and citizenship behavior: The target similarity model. J. Manag. 2007, 33, 841-866. [CrossRef]

54. Colquitt, J.A.; Rodell, J.B. Justice, trust, and trustworthiness: A longitudinal analysis integrating three theoretical perspectives. Acad. Manag. J. 2011, 54, 1183-1206. [CrossRef]

55. Audretsch, D.B. Innovation and Industry Evolution; MIT Press: Cambridge, MA, USA, 1995.

56. Miranda, F.J.; Chamorro, A.; Rubio, S. Determinants of the intention to create a spin-off in Spanish universities. Int. J. Entrep. Innov. Manag. 2017, 21, 299-317. [CrossRef]

57. Miranda, F.J.; Chamorro, A.; Rubio, S. Re-thinking university spin-off: A critical literature review and a research agenda. J. Technol. Transf. 2017, 43, 1007-1038. [CrossRef]

58. Díaz-Casero, J.C.; Hernández-Mogollón, R.; Roldán, J.L. A structural model of the antecedents to entrepreneurial capacity. Int. Small Bus. J. 2012, 30, 850-872. [CrossRef]

59. Abreu, M.; Grinevich, V. The nature of academic entrepreneurship in the UK: Widening the focus on entrepreneurial activities. Res. Policy 2013, 42, 408-422. [CrossRef]

60. MCIU. Datos y Cifras del Sistema Universitario Español. Curso 2018/2019; Madrid, Spain. Available online: https: //www.ciencia.gob.es/portal/site/MICINN/menuitem.26172fcf4eb029fa6ec7da6901432ea0/?vgnextoid=364e006e96052 710VgnVCM1000001d04140aRCRD (accessed on 25 February 2021).

61. Chin, W.W. The partial least squares approach to structural equation modeling. In Modern Methods for Business Research; Marcoulides, G.A., Ed.; Lawrence Erlbaum Associates: Rahwah, NJ, USA, 1998; pp. 295-336.

62. Hulland, J. Use of partial least squares (PLS) in strategic management research: A review of four recent studies. Strateg. Manag. J. 1999, 20, 195-204. [CrossRef]

63. Carmines, E.G.; Zeller, R.A. Reliability and Validity Assessment; Sage Publications: Beverly Hills, CA, USA, 1979 ; Volume 17. 
64. Nunnally, J.C. Psychometric Theory; McGraw-Hill: New York, NY, USA, 1978.

65. Fornell, C.; Larcker, D.F. Structural Equation Models with Unobservable Variables and Measurement Error: Algebra and Statistics; Sage Publications: Los Angeles, CA, USA, 1981.

66. Barclay, D.; Higgins, C.; Thompson, R. The partial least squares (PLS) approach to casual modeling: Personal computer adoption and use as an illustration. Technol. Stud. Spec. Issue Res. Methodol. 1995, 2, 294-324.

67. Teo, T.S.H.; Srivastava, S.C.; Jiang, L. Trust and electronic government success: An empirical study. J. Manag. Inf. Syst. 2008, 25, 99-132. [CrossRef]

68. Falk, R.F.; Miller, N.B. A Primer for Soft Modeling; University of Akron Press: Akron, OH, USA, 1992.

69. Henseler, J.; Ringle, C.M.; Sarstedt, M. A new criterion for assessing discriminant validity in variance-based structural equation modeling. J. Acad. Mark. Sci. 2015, 43, 115-135. [CrossRef]

70. Siegel, D.S.; Wright, M. Academic entrepreneurship: Time for a rethink? Br. J. Manag. 2015, 26, 582-595. [CrossRef] 